\title{
Resilience of Inland Urban Areas to Disasters Occurred Due to Extreme Precipitations
}

\author{
Saja Kosanović ${ }^{1, *}$, Linda Hildebrand ${ }^{2}$, Gordana Stević ${ }^{3}$ and Alenka Fikfak ${ }^{4}$ \\ ${ }^{I}$ Faculty of Technical Sciences, Kneza Miloša 7, 38220 Kosovska Mitrovica, Serbia \\ ${ }^{2}$ Rheinisch Westfaelische Technische Hochschule (RWTH), Templergraben 83/4.OG, 56062 Aachen, Germany \\ ${ }^{3}$ Republic Hydrometeorological Service of Serbia, Kneza Višeslava 66, 11000 Belgrade, Serbia \\ ${ }^{4}$ Faculty of Architecture, Zoisova 12, SI-1000 Ljubljana, Slovenia
}

\begin{abstract}
Among possible manifestations of climate change, which, according to predictions for coming period, may occur in different regions of Europe, are the extreme precipitations. These events, often accompanied by storms, may further lead to a whole series of consequences in urban environment and to the occurrence of disasters, such as massive floods. Starting from the description of case of Serbia floods 2014, this paper identifies some of the past human mistakes with experienced (and possibly future) catastrophic consequences, gives overview of future climate change expectations in terms of extreme precipitation occurrence, considers possible negative implications on urban population, built environment and functions, and defines resilient city concept. Finally, the paper introduces strategic proposal on achieving flood-resilient cities. Proposed concept deals both with the mitigation of past errors and the introduction of new, climate-resilient practice in further urban development. Time gap between future (with supposed achieved resilience) and present moment (with supposed high level of vulnerability and therefore risks) is overcome by definition of priorities and introduction of three different time-related categories of actions and results: immediate, short-term and long-term. Achieving social preparedness for possible extreme weather events represents the first important step in reducing the possibility of their negative transformation into disaster.
\end{abstract}

Keywords: Climate change, extreme precipitation, floods, natural-technological disasters, Obrenovac town, time effects, urban resilience strategy development.

\section{INTRODUCTION}

During the third week of May 2014, massive floods caused by heavy rainfall, and consequently by increase of water levels in some main rivers, hit several regions of Republic of Serbia. Heavy rainfall and rising water levels had three immediate and direct effects: high intensity flash floods resulting it total destruction in built environment; rising water levels resulting in the widespread flooding in both urban and rural areas; and increased flow of underground waters leading to widespread landslides. Combination of rainfall, soil saturation and instability additionally led to the activation of landslides in inhabited and uninhabited areas. The disaster affected (directly and indirectly) around 1.6 million people living in 38 municipalities [1]. Many houses, apartment buildings, bridges, schools, administrative buildings, roads, infrastructural networks and facilities, etc. were damaged or destroyed. Losses were human, physical, economic, social, and environmental. Flood wave reduced the reliability of energy transport systems; the state in two major plants for

*Address correspondence to this author at the Kneza Miloša Str. N7, 38220 Kosovska Mitrovica, Kosovo/Serbia; mob: +381638274552;

E-mail: saja.kosanovic@pr.ac.rs electricity generation was critical. Army and police forces, civil protection, health services, volunteers from various organizations, international rescue teams and citizens themselves were all involved in providing help. Evacuation of about 32,000 persons was organized, as well as the supply with water, food and medications for those who stayed at their home or work place [2]. The disaster resulted in 51 casualties, 23 of which were due to drowning [1].

Obrenovac - municipality within metropolitan area of the Capital of Serbia, with about 75,000 residents, was heavily affected (Fig. 1). On $16^{\text {th }}$ of May 2014, due to the outflow of river Kolubara, $80 \%$ of territory of Obrenovac was flooded. Energy supply and telecommunication links were cut. About 25,000 citizens were evacuated [2] (Fig. 2).

Despite the onrush of water to the town, which lasted for days, simultaneous actions were taken on its extraction. To support evacuation and rescue, radio relay link and aggregates for mobile telephony base stations were installed. Biological decontamination and collection of abandoned, lost or dead animals and of tainted food were organized. After water retreat, expert teams documented major damage on more than 3,000 single-family houses and 1,200 residential units within apartment buildings [3] (Figs. 3 and 4). 


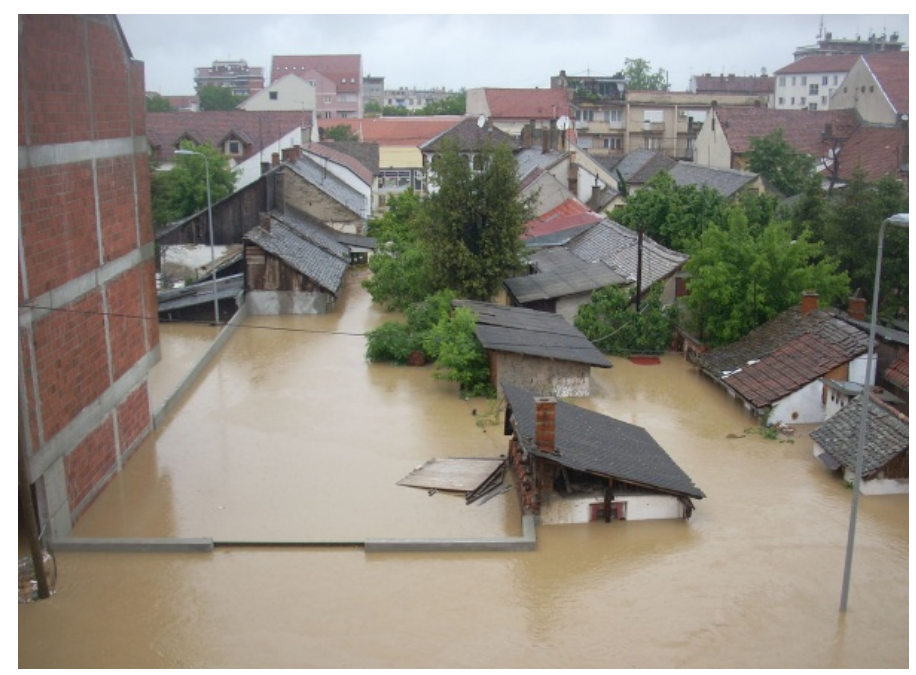

Fig. (1). Part of Obrenovac during floods on May 2014.

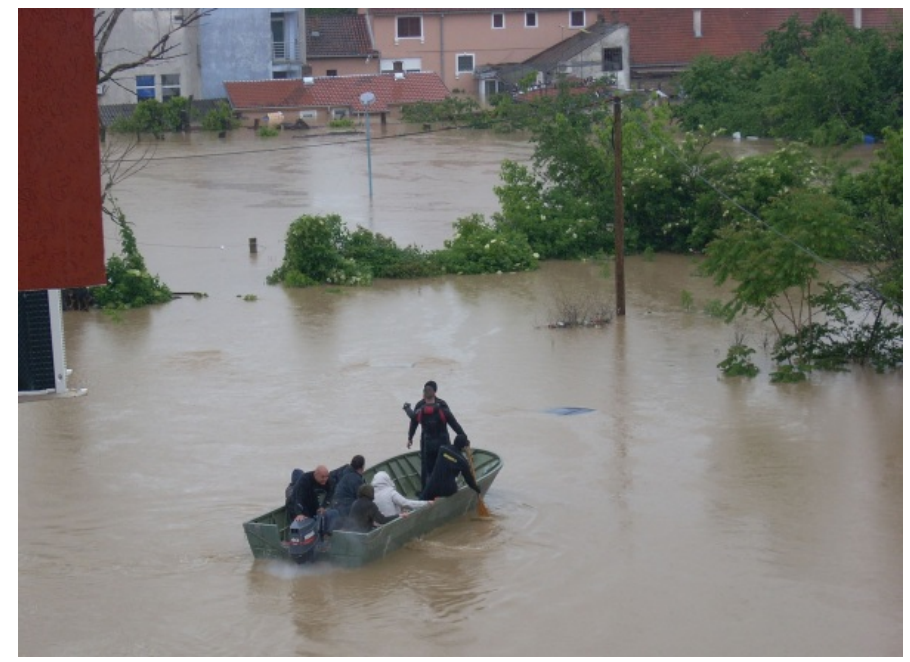

Fig. (2). Evacuation of vulnerable population.

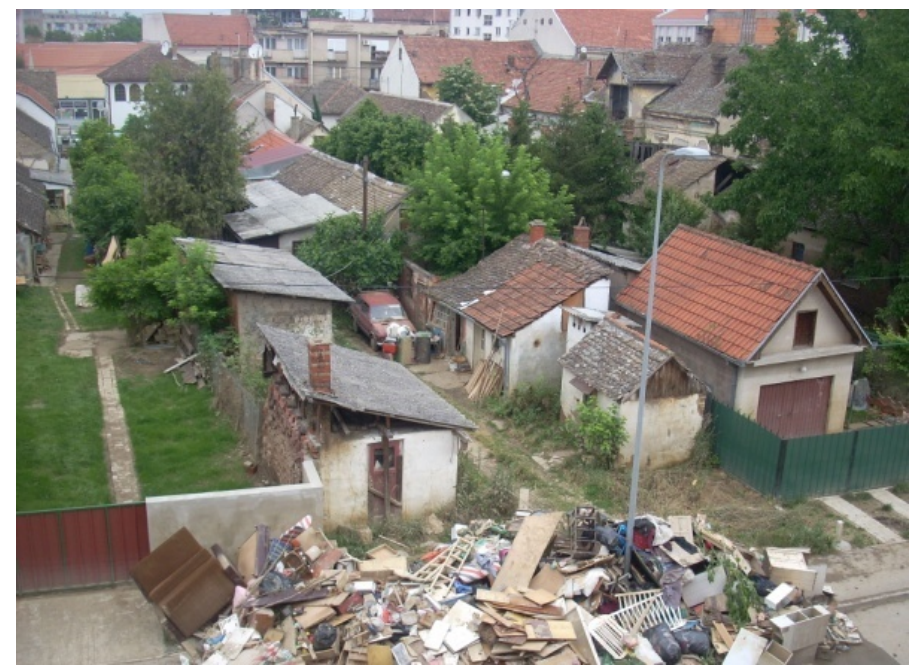

Fig. (3). Area shown on Figure 1 after water retreat. 


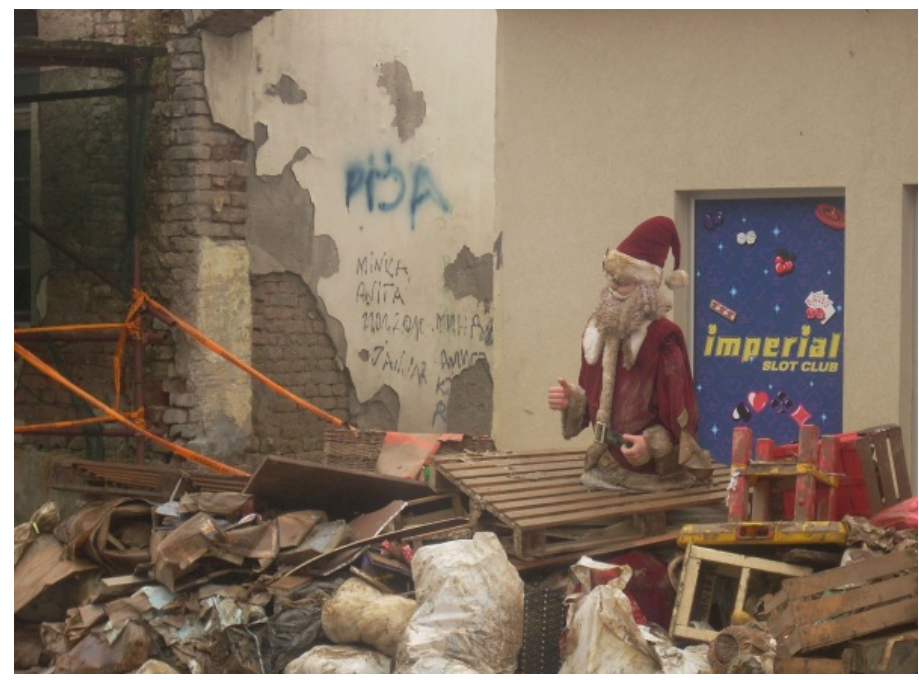

Fig. (4). Damages and cleaning.

Among reasons which led to transformation of heavy rainfall into disaster, both in Obrenovac and wider, in other regions of the Republic of Serbia, are: urban development in flood fields and uncontrolled settlement growth, inappropriate construction, poor infrastructure, sealed areas and lack of green urban spaces, uncontrolled construction on river banks, poor public sewerage systems, inappropriate use of building materials, weak regulation of river beds, weak protection of river banks, poor maintenance of existing protection systems, outdated and insufficient protection equipment which doesn't meet the demands in a case of large number of simultaneous flood events, lack of financial resources, etc. [1-3].

With the accent on inland urban areas, this paper aims to investigate relation between climate change, extreme weather events (extreme precipitation) and disaster occurrence, to describe human errors which contribute to the transformation of extreme weather events into disasters, to define concept of resilience in terms of flood-proofing, and finally to propose framework for achieving flood resilience of cities, by taking into account technical, environmental, social and economic measures.

\section{CLIMATE CHANGE AND RELATED DISASTERS}

2014 Intergovernmental Climate Change (IPCC) Synthesis Report emphasizes new results since the publication of previous document in 2007. During these seven years, the evidence for human influence on climate system has grown. In turn, climate change (manifested in rise of surface temperature, extreme precipitation, warming and acidification of the ocean, and rise of global mean sea level) and world-wide climate-related extremes (floods, droughts, heat waves, wildfires, cyclones, occasional cold winter extremes, etc.) reflect and will continue to reflect on alteration of ecosystems, disruption of food production and water supply, damage to infrastructure and settlements, human morbidity and mortality, and consequences to mental health and human well-being. Even if greenhouse gases emissions will be cut, climate will continue to change under all scenarios; preparation is therefore necessary. "Future climate change will amplify existing climate-related risks and create new risks" [4]. "The risks of abrupt or irreversible changes increase as the magnitude of the warming increases" [4].

Extreme events occurring due to climate change often lead to disasters in built environment. In Europe, key risks related to climate change refer to increased damages from river and coastal floods, increased water restrictions and increased damages from extreme heat events and wildfires [4]. Changes in precipitation patterns across Europe point at variable outcomes. In northern Europe, for example, the winters will become wetter, while in Mediterranean area summers will be drier [5]. In some other regions, such as one including territory of the Republic of Serbia, the overall precipitation won't be changed significantly, but the regimes will [6]. Number, intensity and duration of extreme precipitation events are expected to increase in various European regions [5]. Trend in reporting river floods across Europe is also increasing: more than 325 major floods have been reported since 1980, of which more than 200 after 2000 [7].

Climate change is projected to increase the occurrence and frequency of flood events in large parts of Europe, though the estimates of changes remain uncertain [7]. Projections show further increase in risk of river floods in many western European and central eastern European areas. Risk of urban drainage flooding is particularly high in western and northern Europe [5]. Floods will occur not just because the receptive capacity of rivers to accept rainfall will be exhausted, but also from series of other reasons, based on which their typology is made. Thus, floods can be distinguished based on the source of flooding (rivers and lakes, urban storm water and combined sewage overflow, or sea water), the mechanism of flooding (natural exceedance, defence or infrastructural failure, or blockage, for example) and some other characteristics (such as flash flooding, snowmelt flood, or debris flow) [7]. 
Extreme precipitation events are unpredictable and uncontrollable. Due to these facts, additionally supported by rapid and significant changes in climate, society didn't have enough time to prepare for present moment; many lessons today are learned from past human mistakes. Often, these errors are perceived after a disaster occurred. The fight against climate change related disasters should thus include efforts to minimize past errors, to change the direction of present actions, and to plan for safer future. Climate change and its nature condition communities at all levels and in all parts of the world to continuously seek for the modes to minimize negative effects of catastrophic events before they happen, if they ever happen.

\section{Fight Against Climate Change}

There are two main directions to fight against climate change impacts, including the occurrence of disasters: mitigation and adaptation.

Early worldwide actions related to climate change were mostly focused on mitigation. Shifts in energy demand, supply, generation and resources, and energy leakage prevention; modifications of transport infrastructure, methods and means; transformations of urban and architectural forms and infrastructure (through new development or retrofit); behavioural changes; introduction of new technologies, etc. all denote the efforts to reduce greenhouse gases emissions and thus to mitigate climate change occurrence. But, "as the inevitability of climate change becomes more apparent, an understanding has grown that we do not only need to address the causes, but also the impacts of climate change" [4].

Both types of actions could be elaborated from global to local level, as these levels overlap and therefore negative changes provoked by chain effect reaction penetrate into every of them. While mitigation aims to achieve substantial and sustained reduction in greenhouse gases emissions, adaptation, simultaneously, deals with the exposure (of people and assets) and vulnerability (susceptibility to harm) of human and natural systems [4]. Finally, both mitigation and adaptation relate to reduction of risks.

\section{Why Cities?}

Ratio between urban and rural population constantly changes. In $2014,54 \%$ of world's population resides in urban areas; by $2050,66 \%$ of the world's population is projected to be urban [8]. With the increase of urban population, sustainable development challenges will be concentrated in cities, especially in lower-middle-income countries; consequently, the vulnerability will increasingly become urbanized [9]. Cities concentrate economic activity, population, and critical infrastructure, and at the same time, risk associated with climate change [10]. Action in urban centres is essential to successful global climate change adaptation [11].

According to the predictions for coming period, and depending on geographic location and distribution of negative climate change effects, urban areas around the globe will in future time be increasingly exposed to different extreme weather events. In Europe, increased flooding is likely to be one of the most serious effects from climate change over coming decades [12].

Extreme precipitation in inland urban areas, possibly accompanied by storms and leading to floods, cause: damages to property, infrastructure, transportation, supply systems and services, including energy sector, wastewater, freshwater and rainfall drainage systems; environmental pollution and degradation; damages to urban ecosystems; especially significant damages to more vulnerable people, groups and communities; changes in population health, productivity, activities and safety; malnutrition; reduced water availability for sanitation and drinking; risk of water contamination; forced migrations; mudslides; landslides; erosion and many other direct or indirect negative consequences which impact not just the affected areas, but also distant locations.

\section{From Extreme Precipitation to Disaster in a City}

Causes of negative transformation by which an extreme precipitation event turns at one point into disaster characterized by massive flooding should be observed both as natural and anthropogenic. Bell, Greene, Fisher and Baum debate on what constitutes a natural disaster, trying to find the most comprehensive definition. The authors propose the inclusion of social dimension in order to determine the term: natural disaster must provoke the disruption in affected community in order to be named as such [13]. Same does the technological disaster caused by human acts. Climate change related disasters in built environment, it may be concluded, originally triggered by natural extreme event, will either be intensified or mitigated, depending on human factor. Flood, for example, often is the consequence both of extreme precipitation and bad planning, protection and maintenance practice, as was the case with Obrenovac.

Natural causes which contribute to occurrence of floods in urban areas relate to geographic position of affected city, exposure to climate change manifestations and other meteorological and hydrological factors. If many of today's cities were founded in far past, and if locations for their formation were chosen carefully (one of the main postulates of indigenous practice), it is than obvious that climate has changed; locations which were once considered safe possibly don't own this quality any more. Wrong selection of location for settlement establishment in minor, but still important number of cases equally contributes to higher risk to flood occurrence. Other human errors which are regarded as responsible for occurrence of flooding disasters in cities are: planning and building without taking into consideration the possible extreme precipitation; inadequate capacity of recipient systems to support extreme rainfall; sealing of the urban areas (for example, Paris and Bucharest have more than three quarters of their surface area sealed [12]); inappropriate land use and flood management in upstream regions [5]; rapid and unsustainable urban growth, often into unsuitable areas, such as floodplains; informal urban development and construction - illegal construction, slums; fail in quick response to disaster; rural/urban migrations; poor infrastructure, especially in edge areas; weak social protection systems; weak 
regulation and protection of water beds; dependence of a city on external services; lack of education and knowledge; inadequate or nonexistent institutional and legal frameworks, etc.

Urban areas at higher risk to floods are low-lying areas, floodplains, erosive slopes or in any other way exposed locations. In regard to urban systems, equally vulnerable are low, mid- and high-developed and industrialized areas relying on structure and systems that are incapable of coping with climate change related natural disasters [10].

\section{RESILIENT CITY CONCEPT}

Similar to general orientation, early interest in climatechange related actions in urban areas was directed towards climate change mitigation and mostly related to energy efficiency concepts. However, frequent and numerous recent disasters triggered by extreme weather events and followed by catastrophic consequences, which occurred in worldwide urban areas, call upon the need to deal with resilience. In various new published sources, term resilience is often associated with the capability to adapt to various changeable circumstances which are interpreted as climate change manifestations. Therefore, it may be commonly found that a resilient city is named as an adaptive city.

In some sources, resilience of urban areas was associated with natural hazards and disasters, but these were not linked to climate change. Back in 2003, for example, Godschalk proposed a comprehensive strategy of urban hazard mitigation aimed at the creation of resilient cities, able to withstand both natural hazards (floods, earthquakes and hurricanes) and terrorism. Without stated concern for climate change involvement in natural hazards occurrence rate and strength, author places mitigation actions as a key to reduce or eliminate risk to people and property from hazards and their effects. According to Godschalk, resilient cities would be capable of withstanding severe shock without either immediate chaos or permanent harm [14]. By this definition, the author actually introduces adaptation. Roaf, Crichton and Nicol place strong emphasis in their work on necessity for adaptation strategies. Putting themselves in role of users, these authors raise several concerning questions, from "Will the house flood next year?" or "Where will we go?" to "Will we survive?" [15].

At the base, contemporary concept of resilient city relates in the major part to vulnerability of urban environment: its natural, built, social and economic dimensions. By arguing that any destruction in built environment further disturbs functioning of human society, and economic and social development, authors Molin Valdes, Amaratunga and Haigh assign paramount importance of a resilient built environment in achieving resilient cities [16]. Between vulnerability, exposure and risk of climate related extreme weather event occurrence, first one allows the most of interventions on adaptation (this is why resilience concept is introduced), while exposure often relates to geographic position of certain area. Risk of climate related extreme weather occurrence, related to past experience and future predictions, can be embodied into adaptive strategies just as starting fact, but not as possible field of interventions on adaptation (this could be expected to become long-term result of climate change mitigation measures, in the best case).

Efforts to prevent next disaster must be consistent, opposite from common current practice when adaptation stops as soon as the "life goes back to normal". This is so called crisis effect which "refers to the fact that awareness of or attention to a disaster is greater during and immediately following its occurrence, but greatly dissipates between disasters" [13].

Among recent global initiatives to increase city resilience, project "100 Resilient Cities" stands out. Aim of the challenge is to help cities to adopt innovative approaches and build resilience to the unprecedented physical, economic, and social challenges that mark the $21^{\text {st }}$ century, and to, at the same time, develop network of cities in different regions of the world. Created City Resilience Framework distinguishes four dimensions of urban resilience: Health and Wellbeing (meets basic needs in crisis, supports livelihoods and employment, and ensures public health services); Economy and Society (promote cohesive and engaged communities, ensure social stability, security and justice, and foster economic prosperity); Leadership and Strategy (promote leadership and effective management, empower a broad range of stakeholders, and foster long-term and integrated planning); and Infrastructure and Environment (provide and enhances protective natural and man-made assets, ensures continuity of critical services, and provide reliable communication and mobility) [17].

European Environment Agency (EEA) proposes within report published in 2012 the adaptation actions to flooding in cities and regions, dividing them into three groups: grey, green and soft measures [5].

Different European research projects, such as: FloodResilienCity [18], SMARTeST [19], or UrbanFlood [20], deal with floods in urban areas. In European legislation, Floods Directive (2007/60/EC) determines assessment and management of flood risks and obliges all member states to assess if all water courses and coast lines are at risk from flooding, to map the flood extent and assets and humans at risk in these areas and to take adequate and coordinated measures to reduce this flood risk [21, 22]. Earlier Communication on flood prevention, protection and mitigation (COM/2004/0472 final) sets in its annex the guidelines for development and implementation of flood risk management plans, grouped into: principles for the development of flood risk management plans; objectives of the introduction of the plans; key outputs; and development of flood risk maps [23].

How resilient city relates to sustainable city is one of the leading ongoing debates. While for some authors, such as [24], resilience actually means new sustainability, for others, who go into more complex analysis, the two systems should to be observed as individual, but linked concepts promoting a plurality and diversity of solutions to social-ecological problems [25]. "Resilience can reinforce both sustainable and unsustainable developmental pathways. Harnessing 
resilience to reinforce system dynamics that promote sustainability is the key to achieving future desired sustainability states" [25]. Dualities among these two concepts, observed, for example, in construction material selection or promotion of compact cities with high population densities, need to be reconciled with the development of new approaches.

\section{Adaptive Response of Urban Population}

In adaptation of urban areas to climate change, technical, physical and socio-psychological capacities of urban population are equally important.

"People who are socially, economically, culturally, politically, institutionally or otherwise marginalized are especially vulnerable to climate change and also to some adaptation and mitigation responses. This heightened vulnerability is rarely due to a single cause. Rather, it is the product of intersecting social processes that result in inequalities in socioeconomic status and income, as well as in exposure. Such social processes include, for example, discrimination on the basis of gender, class, ethnicity, age, and (dis)ability" [4]. Risks are generally greater for disadvantaged people in communities in counties at all levels of development [4].

Many different sources cite that the poor are the most vulnerable to natural disasters, due to low quality of life, lack of education, weak housing standards, problematic location and worrisome growing number of slum dwellings in countries around the world. "When disaster strikes they have few or no private assets or social safety nets to fall back upon" [9].

Floods cause loss of life and disease due to exposure to contaminated water, damp and associated fungi. Children, the elderly and people in poor health generally are at risk [5]. Life threat, injury, witnessing injury or death, death or injury of relative or friend, preparedness of community, social cohesion of community, financial, property and possessions' loss, separation from family, etc. are all the factors which will dictate the response in case of disaster [13]. Posttraumatic syndrome is a common consequence of suffered disasters. Individual response to occurred extreme events also depends on personal psychological perception and further to arousal and/or stress and/or overload and/or reactance. If a person copes successfully with negative change, adaptation and/or adjustment will follow. Oppositely, arousal and/or stress, with the possibility to become more intensive due to inability to cope, will continue. In coping process, health, performance, and social behaviour may be affected [13].

Communities living in areas in which extreme climate persists for centuries had enough time to biologically adapt. "These adaptations may even be genetic, such that ancestors with these adaptive characteristics were more likely to survive the extremes and pass their hereditary characteristics along to the next generation" [13]. Oppositely, today's rapidly changing conditions find the residents of cities unprepared. It is therefore essential to develop comprehensive support network aimed to minimize negative impacts of extreme events on urban population.

\section{ACHIEVING THE RESILIENCE: PROPOSAL FRAMEWORK}

"Adaptation is place- and context-specific, with no single approach for reducing risks appropriate across all settings. Effective risk reduction and adaptation strategies consider vulnerability and exposure and their linkages with socioeconomic processes, sustainable development, and climate change" [4].

Resilience of urban areas represents challenging research topic for different authors. Various guidelines of achieving resilience have been developed, from general strategies to proposals for specific areas created in line with predicted possible occurrence of extreme events. Determination of vulnerability and exposure, and risk assessment represent initial steps in the development of such proposals.

According to recent extreme weather events and consequent disasters, predictions for coming period, and identified human past errors, it may be concluded that actions in achieving resilience of inland urban areas to floods need to be directed both towards the correction of previous mistakes and the development of new concept for future. Additionally, present moment in which we are, unprotected and as such exposed to higher risks to disasters due to existing vulnerability, must also be taken into consideration. In any case, time factor plays multiscalar, crucial role. "Adaptation can reduce the risks of climate change impacts, but there are limits to its effectiveness, especially with greater magnitudes and rates of climate change. Taking a longer-term perspective, in the context of sustainable development, increases the likelihood that more immediate adaptation actions will also enhance future options and preparedness"[4]. Strategic approach to resilience of urban areas is, therefore, time related, involving social, economic, environmental and technical aspects. Strategy must be composed in a way that risks related to adaptation, such as maladaptation or negative ancillary impacts, are avoided. Appropriately conducted assessments of vulnerability, future climate risks, current and changing socio-economic conditions and the adaptive capacity $[26,27]$, therefore play crucial role.

The backbone of the strategy should be shaped on national level. At this instance, the first step should be dedicated to distinguishing among the actions with immediate, short- and long-term effects, as well as to the assignments of local authorities in their further elaboration. "Adaptation planning and implementation can be enhanced through complementary actions across levels, from individuals to governments. National governments can coordinate adaptation efforts of local and subnational governments, for example by protecting vulnerable groups, by supporting economic diversification, and by providing information, policy and legal frameworks, and financial support. Local government and the private sector are increasingly recognized as critical to progress in adaptation, given their roles in scaling up adaptation of communities, households, and civil society and in managing risk information and financing" [4]. "Local governments are the units best placed to implement informed decisions in areas such as land-use planning, building standards, freshwater supply, wastewater and waste management, transportation etc." [10]. On the other hand, regional 
Table 1. Time scale of actions and results on achieving flood resilience in inland urban areas.

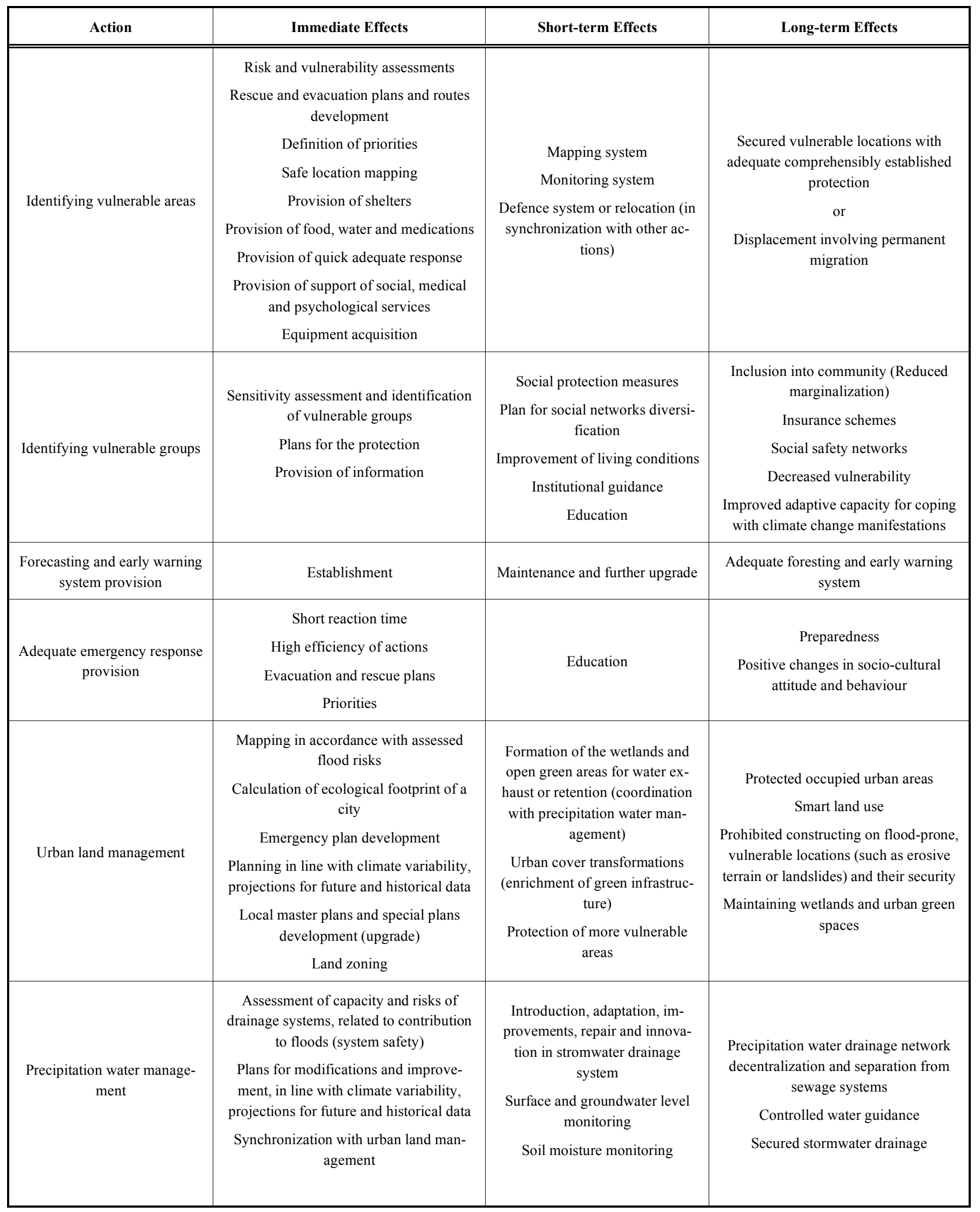


Table 1. contd...

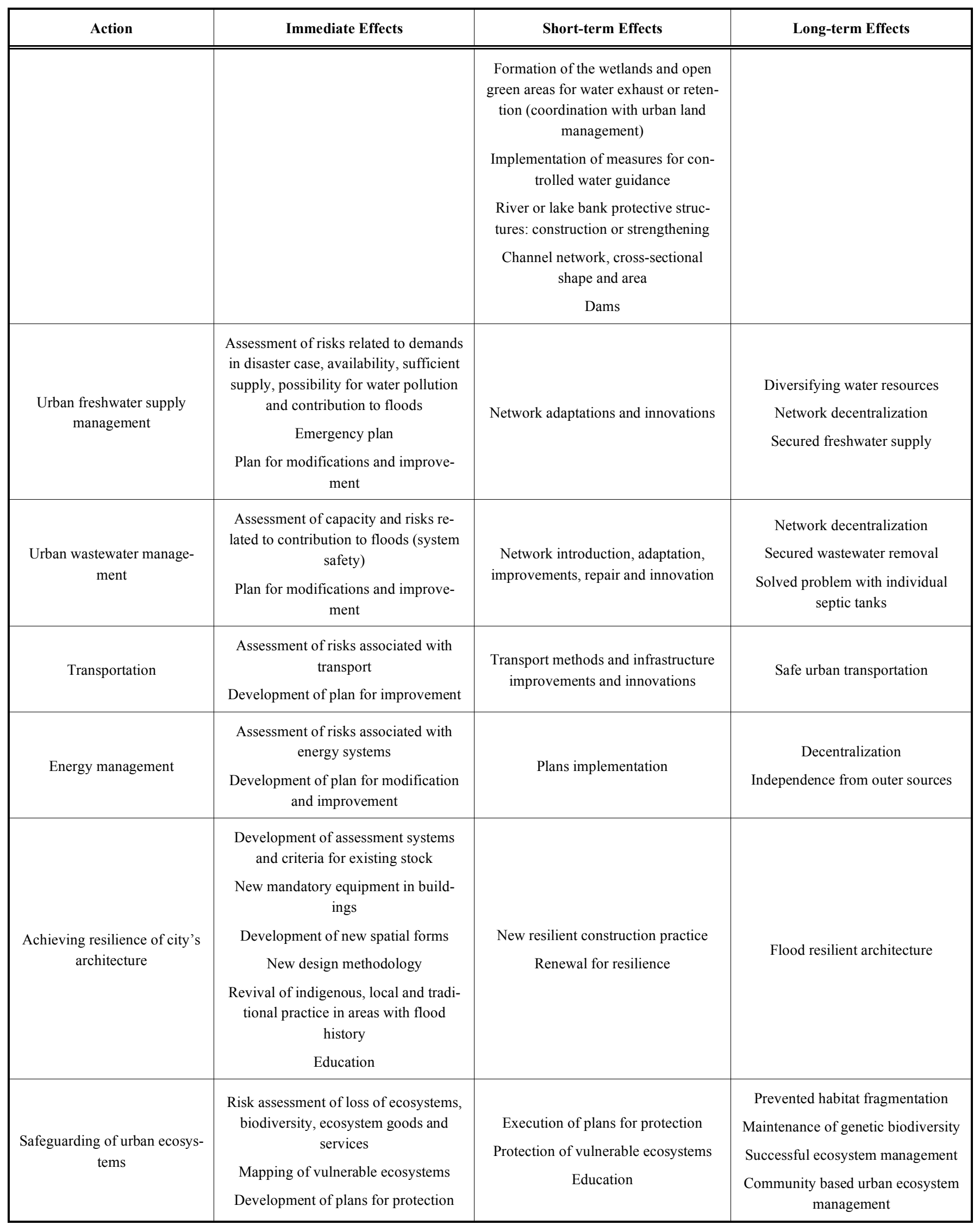


Table 1. contd...

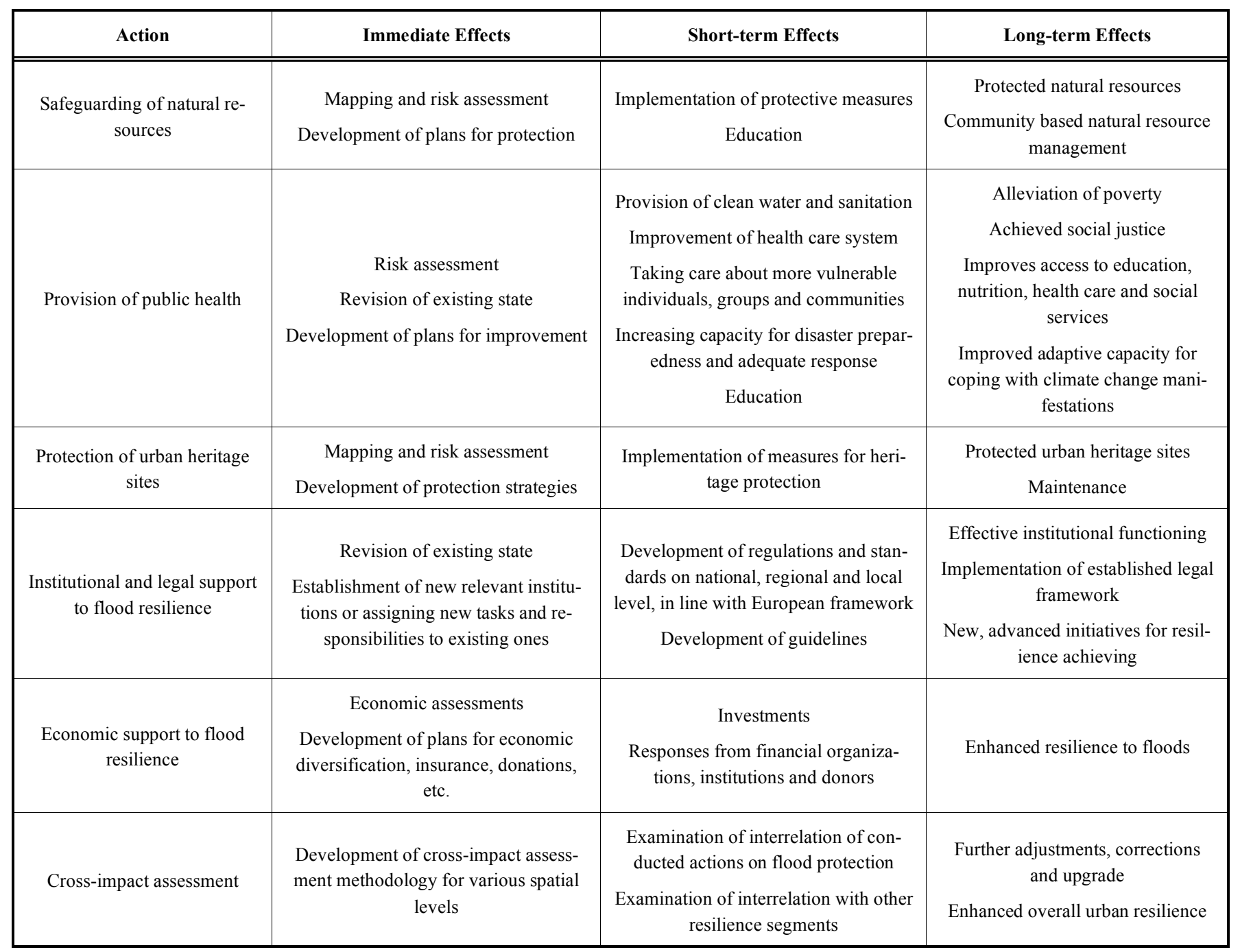

approach helps in dealing with certain problems, such as pluvial and fluvial floods, as risks in a city can strongly be influenced by factors outside the city boundaries such as upstream river management [7].

Table 1 shows proposed time scale of actions and results on achieving flood resilience in inland urban areas. Listed actions aim to individually contribute to the overall resilience of a city. Resilient systems withstand, respond to, and adapt more readily to shocks and stresses to emerge stronger after tough times, and live better in good times [17].

In line with professional interest, the characterization of resilient architecture represent separate research topic. In this sense, new research question arises: How will the adaptation to climate change affect current design practice? Key concepts relate to the application of building materials and construction concepts (water-proof and easy-dry architecture); form (for example, floating or elevated structures); new technology development, but also revival of indigenous, traditional practice; treatment of the basement and ground floor of architectural structures; building services and equipment; and, finally, further treatment and need for mobile architectural structures.

\section{CONCLUSION}

Strategy proposed in this paper aims to influence on human activities and to, as such, reduce the risk of consequences of extreme precipitation to human life, health, natural and built urban environment, infrastructure and cultural heritage in cities. Measures to reduce these risks are defined in line with the objectives of their implementation, and grouped according to common objective of main subject action. To substantially reduce risk from flooding due to extreme precipitation in urban areas, it is very important to initiate all listed actions simultaneously, although it is considered that each of these will give its part of contribution.

Chronologic progress of achieved resilience to floods in urban areas is divided into three time-related categories for every main action. First category represents the initiation of urban transformations towards resilience; it concerns present moment and includes measures for protection of the most vulnerable areas and groups, but also relates to the risk assessment within every main action, and as well to the development of plans and establishment or provision of institutional, legal and economic support. Second category within every main action encompasses both short-time results of 
previously taken measures and implementation of measures which demanded more preparation for execution. Finally, third category relates to the long-term achieved results, i.e. achieved resilience, and to its further enhancement. Established time scale enables simplified determination of priorities and therefore may be considered especially useful in those areas in which the organized actions against climate change still didn't begin; depending on the specificities of different case studies, these priorities may be subject of change.

Differently from developed strategies which accent at the first place the achievement of technical-technological resilience of a city, proposal described in this paper gives priority to social dimension - urban population and its adaptive capacity building. Allocation of priorities came from one side due to uncertainty and unpredictability of occurrence of extreme weather events, and from other due to their experienced consequences on population. Social preparedness for possible extreme weather events reduces the possibility of their negative transformation into disaster.

\section{CONFLICT OF INTEREST}

The funding sources had no involvement in conducting the research and preparing the manuscript of this paper.

\section{ACKNOWLEDGEMENTS}

All listed authors substantially contributed to this paper: Saja Kosanović and Alenka Fikfak designed the research, collected and analyzed data, and wrote the paper; Linda Hildebrand designed time-oriented proposal concept, collected and analyzed data on urban resilience; Gordana Stević collected and analyzed data on climate change, related hazards and consequences.

Authors express gratitude to Vesna Urošević, the resident of Obrenovac who contributed to this paper with photographs from her personal archive.

\section{REFERENCES}

[1] United Nations Serbia, European Commission and World Bank Group. Serbia floods 2014. Belgrade, 2014.Retrieved on November 10, 2014. Available from: http://ec.europa.eu/enlargement/pdf/press_corner/floods/20140715-serbia-rna-report.pdf

[2] Vlada Republike Srbije. Izveštaj o elementarnoj nepogodi poplavi koja je zadesila Republiku Srbiju i merama koje su preduzete radi spasavanja stanovništva i odbrane ugroženih mesta od poplava (eng. Report on natural disaster - flood that befell the Republic of Serbia, and on measures taken to rescue population and to defend places endangered to flooding). Beograd, 2014. Retrieved on October 28, 2014. Available from: http://www.parlament.gov.rs/upload/archive/files/cir/pdf/akta_procedura/2014/2220-14.pdf

[3] Pokret Udruženi. Izveštaj o proceni potreba nastalih usled poplava u maju 2014 (eng. Report on assessment of the needs raised by floods on May 2014). Beograd, septembar 2014.Retrieved on October 26, 2014. Available from: http://www.udruzeni.org/wpcontent/uploads/2014/09/Izvestaj-poplave.pdf

[4] Pachauri RK, Meyer LA, Eds. Climate Change 2014: Synthesis report of the IPCC $5^{\text {th }}$ Assessment Report (AR5). Longer report. Adopted on $1^{\text {st }}$ November 2014. Retrieved on November 10, 2014. Available from: http://www.ipcc.ch/report/ar5/syr/

[5] European Environment Agency. Urban adaptation to climate change in Europe: Challenges and opportunities for cities together with supportive national and European policies. EEA Report. $\mathrm{N}^{\circ} 2$
(2012). Office for Official Publications of the European Union, Luxemburg, 2012. Retrieved on November 4, 2014. Available from: http://www.eea.europa.eu/publications/urban-adaptation-toclimate-change

[6] Popović T, Đurđević V, Živković M, Jović B, Jovanović M. Promena klime u Srbiji i očekivani uticaji (eng. Climate change in Serbia and expected impacts). Fifth regional conference EnE09 Environment towards Europe, Ministry for environmental protection and Agency for environmental protection of Republic of Serbia, Belgrade, Serbia, 2009. Retrieved on October 26, 2014. Available from: http://www.sepa.gov.rs/

[7] European Environment Agency. River floods (CLIM 017): Assessment. November 2012. Retrieved on November 3, 2014. Available from: http://www.eea.europa.eu/data-andmaps/indicators/river-floods-1/assessment

[8] World Urbanization Prospectus (2014 Revision): Highlights. United Nations, 2014.Retrieved on November 10, 2014.Available from: $\quad$ http://esa.un.org/unpd/wup/Highlights/WUP2014Highlights.pdf

[9] Clos J. Foreword. In: Otto-Zimmermann K, Ed. Resilient cities: cities and adaptation to climate change. Proceedings of the Global Forum 2010, ICLEI-Local Governments for Sustainability, Dordrecht, Heidelberg, London, New York: Springer 2011; pp. vvi.

[10] Otto-Zimmermann K. Building the global adaptation community. In: Otto-Zimmermann K, Ed. Resilient Cities: cities and adaptation to climate change. Proceedings of the Global Forum 2010. ICLEILocal Governments for Sustainability, Dordrecht, Heidelberg, London, New York: Springer 2011; pp. 3-9.

[11] Revi A, Satterthwaite ED, Aragón-Durand F, et al. Urban areas. In: Field CB, Barrosvr, Dokken DJ, et al. Eds. Climate change 2014: impacts, adaptation, and vulnerability, part A- global and sectorial aspects. Contribution of Working Group II to the $5^{\text {th }}$ Assessment Report of the Intergovernmental Panel on Climate Change. USA: Cambridge University Press, 2014; pp. 535-612.

[12] European Environment Agency. Climate change and flood risk in European cities. Retrieved on November 3, 2014. Available from: http://www.eea.europa.eu/highlights/climate-change-and-flood-risk

[13] Bell PA, Greene TC, Fisher JD, Baum A. Environmental Psychology. $5^{\text {th }}$ Ed. New York and London: Psychology Press 2001.

[14] Godschalk DR. Urban hazard mitigation: creating resilient cities. ASCE 2003; 4(3): 136-44

[15] Roaf S, Crichton D, Nicol F. Adapting Buildings and Cities for Climate change: a $21^{\text {st }}$ Century survival guide. Amsterdam: Elsevier and Architectural Press 2005.

[16] Valdes MH, Amaratunga D, Haigh R. Making cities resilient: from awareness to implementation. IJDR 2013; 4(1): 5-8

[17] City Resilience Framework (CRF). The Rockefeller Foundation and Arup, 2014. Retrieved on: November 15, 2014.Available from: http://b.3cdn.net/rockefeller/38915518f389757cce_t6m6bh4ot.pdf

[18] FloodResilienCity. EU project. Retrieved on: November 15, 2014.Available from: http://www.floodresiliencity.eu

[19] SMARTeST. EU project. Retrieved on: November 15, 2014.Available from: $h$ ttp://www.floodresilience.eu

[20] UrbanFlood. EU project. Retrieved on: November 15, 2014.Available from: http://www.urbanflood.eu

[21] European Commission. Environment. Water. Retrieved on: November 12, 2014.Available from: http://ec.europa.eu/environment/water/flood risk/

[22] Directive 2007/60/EC of the European Parliament and of the Council of 23 October 2007 on the assessment and management of flood risks. Official Journal of the European Union: L 288/27, 6.11.2007. Available from: http://eur-lex.europa.eu/legal-content/EN/TXT/?uri $=$ CELEX:32007L0060

[23] Communication from the Commission to the Council, the European Parliament, the European Economic and Social committee and the Committee of the Regions - Flood risk management - Flood prevention, protection and mitigation (COM/2004/0472 final) of 12.07.2004. Available from: http://eur-lex.europa.eu/legalcontent/EN/TXT/?uri=CELEX:52004DC0472

[24] Peng T, Lemay L, Hansen J. Resilience is the new sustainability. Retrieved on: November 16, 2014.Available from: http://www.nrmca.org/resilience/downloads/Resilence_Article.pdf

[25] McPhearson $T$. The rise of resilience: Linking resilience and sustainability in city planning. The nature of cities website. Retrieved on: November 17, 2014. Available from: 
http://www.thenatureofcities.com/2014/06/08/the-rise-ofresilience-linking-resilience-and-sustainability-in-city-planning/

[26] Lim B, Spanger-Siegfried E, Eds. Adaptation policy frameworks for climate change: developing strategies, policies and measures. United Nations Development Programme and Cambridge University Press 2004.
[27] Working Group F of the Common Implementation Strategy for the Water Framework Directive. Resource document of flood risk management, economics and decision making support, 2012. Retrieved on: November 11, 2014. Available from: http://ec.europa.eu/environment/water/flood_risk/pdf/WGF Resour ce_doc.pdf

Received: June 10, 2015

Revised: June 15,2015

Accepted: June 15, 2015

(C) Kosanović et al.; Licensee Bentham Open.

This is an open access article licensed under the terms of the Creative Commons Attribution-Non-Commercial 4.0 International Public License (CC BY-NC

4.0) (https://creativecommons.org/licenses/by-nc/4.0/legalcode), which permits unrestricted, non-commercial use, distribution and reproduction in any medium, provided the work is properly cited. 